\title{
Study of waves in the bays and on the coast of Shikotan Island in the Lesser Kuril ridge
}

\author{
Peter D. Kovalev \\ Dmitry P. Kovalev* \\ Alexander A. Shishkin
}

\author{
Institute of Marine Geology and Geophysics, FEB RAS, \\ Yuzhno-Sakhalinsk, Russia \\ *E-mail:d.kovalev@imgg.ru
}

\begin{abstract}
RUS
The results of a study of waves occurring in the bays of Tserkovnaya, Dimitrov and on the east coast of Shikotan Island (the Lesser Kuril ridge) according to field observations during 2015-2018 are presented. The purpose of the research was to analyse dangerous waves occurring over a wide range of time periods and their manifestations in the bays and coastal zone of the island. It is shown that the bays have well-defined seiche fluctuations, which increase as a consequence of storms. A significant hazard is represented by seiches characterised by harbour oscillation having periods of about 3 minutes in the Bay of Dimitrov and 3.8 minutes in the Bay of Tserkovnaya. The calculation of the Q-factor of the studied bays showed that for waves with periods close to harbour resonance occurring at the entrance of bays, an amplification of the amplitude up to 6.5 times is possible, posing a danger to small vessels moored in the bays during times of storm. It is shown that the propagation of edge waves in the outer coastal zone, which penetrate into both bays, as well as the excitation of the shelf seiche, has a period of about 15 minutes.
\end{abstract}

\section{Keywords}

wind waves, swell, harbor oscillations, seiches, edge waves, Shikotan Island

For citation: Kovalev P.D., Kovalev D.P., Shishkin A.A. Study of waves in the bays and on the coast of Shikotan Island in the Lesser Kuril ridge. Geosistemy perekhodnykh zon = Geosystems of Transition Zones, 2020, vol. 4, no. 2, pp. 250-258 (In Russ.). https://doi.org/10.30730/gtrz.2020.4.2.250-258

Для изитирования: Ковалев П.Д., Ковалев Д.П., Шишкин А.А. Особенности режима волнения в бухтах и на побережье острова Шикотан Малой Курильской гряды. Геосистемы переходных зон, 2020, т. 4, № 2, с. 250-258. https://doi.org/10.30730/gtrz.2020.4.2.250-258

\section{References}

1. Dolgikh G.I., Budrin S.S., Dolgikh S.G., Plotnikov A.A., Chupin V.A., Shvets V.A., Yakovenko S.V. 2016. Free oscillations of water level in the Posyet Gulf bays (the Sea of Japan). Russian Meteorology and Hydrology, 41(8): 559-563. https://doi.org/10.3103/S1068373916080057

2. Earth Observing System Data and Information System. URL: https://worldview.earthdata.nasa.gov (accessed 29.09.2019).

3. Kovalev D.P. 2012. [Experimental studies of the harbor oscillation phenomenon in the main ports of the Sakhalin region]. Mir transporta [World of Transport], 6: 36-43. (In Russ.).

4. Kovalev D.P. 2018. Kyma: The software. RU 2018618773. № 2018612587; registration 20.03.2018; publication 19.07.2018. 
5. Kovalev P.D., Shevchenko G.V., Kovalev D.P. 2007. [Experimental studies of the harbor oscillation phenomenon in the port of Kholmsk]. Izvestiya AIN im. A.M. Prohorova. Prikladnaya matematika i mekhanika [News Academy of Engineering Sciences A.M. Prokhorov. Applied mathematics and mechanics]. Nizhnii Novgorod: NGTU, 20: 106-112. (In Russ.).

6. Kovalev P.D., Kovalev D.P., Khuzeeva M.O. 2019. Estimation of swell wave parameters for predicting storm situations predicting. Gidrometeorologicheskie issledovaniya i prognozy [Hydrometeorological Studies and Forecasts], 2(372): 114-128. (In Russ.).

7. Manilyuk Yu.V., Cherkesov L.V. 2016. Investigation of free liquid oscillations in a bounded basin representing an approximate model of the Sea of Azov. Physical Oceanography, 2: 14-23. https://doi.org/10.22449/1573-160X-2016-2-14-23

8. Manilyuk Yu.V., Cherkesov L.V. 2017. Investigation of seiche oscillations in a free entrance bay. Physical Oceanography, 4: 16-25. https://doi.org/10.22449/1573-160X-2017-4-16-25

9. Manilyuk Yu.V., Lazorenko D.I., Fomin V.V. 2019. Resonance oscillations on the system of adjacent bays. Physical Oceanography, 5: 374-386. https://doi.org/10.22449/0233-7584-2016-2-16-26

10. Munk W.H. 1949. Surf beats. Transactions of the American Geophysical Union, 30(6): 849-854.

11. Rabinovich A.B. 1993. Long ocean gravity waves: Trapping, resonance, and leaking. Saint Petersburg: Hydrometeoizdat, 325 p. (In Russ.).

12. Rabinovich B.I., Tyurin Yu.V. 1983a. [On a recurrent numerical method for conformal mapping]. Doklady AN USSR, 272(3): 532-535. (In Russ.).

13. Rabinovich B.I., Tyurin Yu.V. 1983b. [A recurrent numerical method for conformal mapping of twoconnected regions to a circular ring]. Doklady AN USSR, 272(4): 795-798. (In Russ.).

14. Shevchenko G.V., Chernov A.G., Kovalev P.D., Gorin I.I. 2010. Resonant vibrations in bays and coves: field experiments and numerical modeling. Trudy NGTU im. R.E. Alexeeva $=$ Transactions of NNSTU n.a. R.E. Alekseev, 1(80): 52-62. (In Russ.).

15. Shevchenko G.V., Loskutov A.V., Shishkin A.A., Ivel'skaya T.N. 2017. Features of manifestation of the Chilean Tsunami on April 1, 2014, and September 16, 2015, on Russia's Pacific Coast. Oceanology, 57(6): 870-879. https://doi.org/10.1134/S0001437017060145

16. Shevchenko G.V., Loskutov A.V., Kaystrenko V.M. 2018. A new map of tsunami hazard for the South Kuril Islands. Geosistemy perekhodnykh zon = Geosystems of Transition Zones, 2(3): 225-238. (In Russ.). http://dx.doi.org/10.30730/2541-8912.2018.2.3.225-238

17. Tucker M.J. 1950. Surf beats; sea waves of 1 to 5 min period. Proceedings of the Royal Society of London, A202(1071): 565-573.

18. Zernov N.V., Karpov V.G. 1972. Teoriya radiotekhnicheskih cepej [Theory of radio-engineering circuits]. Leningrad: Energiia [Energy Publ.], 816 p. (In Russ.). 